\title{
MULHERES E HOMENS NA REPRESENTAÇÃO POLITICA - PERFIS SOCIAIS E TRAJETÓRIAS DE PARLAMENTARES NO CONGRESSO NACIONAL
}

\section{WOMEN AND MEN IN POLITICAL REPRESENTATION - SOCIAL PROFILES AND TRAJECTORIES OF PARLIAMEN- TARIANS IN THE NATIONAL CONGRESS}

\author{
Paulo Magalhães Araújo*
}

\section{Introdução}

Uma literatura significativa sobre perfis de parlamentares federais no Brasil mostra crescente profissionalização da elite política nacional. No entanto, é escassa a produção sobre perfis de mulheres parlamentares, seja separadamente ou em comparação com os homens. Mas isso está se revertendo em função de uma vasta agenda de pesquisa que têm sido aberta às minorias políticas em geral e às mulheres em particular.

Este artigo visa a contribuir para o campo com uma análise comparada dos mandatos de homens e mulheres no Congresso Nacional. Pesquisas atuais têm mostrado uma crescente profissionalização política das elites legislativas federais, expressa no acúmulo de cargos políticos ocupados antes e durante a chegada ao Congresso
Nacional. Nesse processo, a especialização acumulada intensifica a competitividade política que, por sua vez, exige maior profissionalização parlamentar. 0 campo político fica cada vez mais racionalizado e institucionalizado, cerrando barreira contra a entrada de não iniciados. A entrada no poder em certos níveis de decisão exige, cada vez mais, experiências anteriores e a posse de recursos que possam ser convertidos em capital político.

Por essa lógica, no presente artigo se supõe que também o contingente feminino que ascende ao legislativo federal é induzido a níveis mais altos de experiência e profissionalização política. Na verdade, a qualificação das mulheres como profissionais da política, a ocupação de cargos expressivos, eletivos e não eletivos, podem ser estratégias eficazes na atração de mais mu-

\footnotetext{
* Professor de Ciência Política do Departamento de Ciências Sociais e do Programa de Pós-Graduação em Ciências Sociais da Universidade Federal do Espírito Santo - UFES - (Vitória/ES/ Brasil). Doutor em Ciência Política. E-mail: pauloaraujomagalhaes@gmail.com
} 
lheres para o mundo da política. Não por acaso, mulheres têm reivindicado, no plano das ideias e na vida prática, instâncias e procedimentos institucionalizados que viabilizem a inserção política feminina.

Têm sido sistematicamente denunciados os obstáculos sociais e político-institucionais enfrentados pelas mulheres na luta pela ascensão a cargos de poder. Soma-se a isso o caráter ainda recente da mobilização feminina mais intensa pela igualdade política ao redor do mundo. Devido a esse fato, espera-se verificar, no Brasil, distinções entre parlamentares federais homens e mulheres no tocante a seus perfis socioprofissionais e suas trajetórias políticas. Espera-se verificar, também, que mulheres - deputadas e senadoras - têm alcançado graus cada vez mais elevados de experiência política, mas ainda inferiores aos demonstrados pelos homens. A questão é saber quanta diferença há entre os sexos e como isso tem mudado ao longo do tempo.

0 artigo está dividido em três tópicos, além desta introdução e das considerações finais. Na primeira parte, discute-se a questão da representação das mulheres, que, sendo maioria demográfica, é minoria no tocante ao controle sobre o poder institucional. A discussão aborda as soluções institucionais atualmente defendidas e criadas para inclusão política das mulheres. Em foco, estarão as listas partidárias, as cotas e a organização interna das listas partidárias. 0 objetivo é ressaltar a relação entre esses elementos institucionais e as possibilidades das mulheres de alcançarem níveis de pro- fissionalização necessários ao efetivo poder de exercer democraticamente a representação política.

No segundo tópico, são analisados quantitativamente $^{1}$ dados de background social relativos a representantes, homens e mulheres, que atuaram no Congresso $\mathrm{Na}-$ cional entre a $47^{\text {a }}$ e a $54^{\text {a }}$ legislaturas, perfazendo oito legislaturas sucessivas, num período de 32 anos. Ao todo, são 5860 casos, sendo 5527 referentes a mandatos de homens e 333 a mandatos de mulheres. Seria interessante se houvesse mais casos de mulheres no conjunto dos dados. Mas, a despeito do reduzido número de mulheres em relação ao de homens, entende-se que a análise não sai prejudicada. Os dados serão tratados em termos percentuais e permitirá uma comparação entre homens e mulheres no tocante às variáveis consideradas.

No terceiro tomo do artigo, com base no mesmo banco de dados, são analisadas informações sobre a trajetória política de homens e mulheres, de modo a indicar similaridades e diferenças entre os sexos no tocante ao leque de experiências alcançadas por cada um na trajetória rumo à representação no Congresso Nacional.

Importa esclarecer que a análise não considera indivíduos, mas mandatos; por isso o número tão grande de casos. Um indivíduo que tenha atuado em mais de um mandato consta no banco tantas vezes quantas tiverem sido seus retornos à casa Câmara ou Senado, conforme o caso. Essa escolha é importante porque permite avaliar a evolução do perfil de cada parlamen-

1. Dado o grande volume de dados, uma análise qualitativa, embora interessante, torna-se inviável. 
tar ao longo dos 32 anos (oito legislaturas) cobertos pela pesquisa. Isso significa que o perfil de uma pessoa pode mudar entre uma legislatura e a ocupada posteriormente, se durante esse período ela, por exemplo, se licenciou para ocupar cargos administrativos, concluiu curso superior ou ocupou outros cargos eletivos e retornou à casa.

Há uma ressalva conceitual a ser feita. Alguns pesquisadores questionam conclusões de estudos que a classe parlamentar brasileira está se profissionalizando. A alegação é a de que o parlamento é apenas um trampolim para os políticos chegarem à chefia do Executivo ou a cargos de alto escalão na administração pública. A atuação em cargos parlamentares seria transitória, um intervalo entre a ocupação de um cargo e outro no Poder Executivo (AMES, 2000; MAINWARING, 1997).

Há outros que refutam essa crítica, observando que sistemas políticos são distintos, assentados em diferentes sociedades, e seus efeitos sobre as projeções da carreira por parte dos políticos também variam. A busca dos políticos brasileiros por uma variedade de cargos públicos não implicaria, assim, descompromisso com a profissionalização. Ao contrário, refletiria outras estratégias para se firmar na profissão política frente aos incentivos oferecidos pela estrutura do sistema federativo brasileiro (DI MARTINO, 2009; SANTOS, 2010). 0 estudo aqui desenvolvido segue este último ponto de vista.

\section{Instituições e representação política das mulheres na contemporaneidade}

A representação de minorias é um problema central nas atuais discussões normativas e empíricas da ciência política. Entre as diversas minorias existentes nas sociedades atuais - com causas específicas de exclusão política e reivindicações próprias por direitos e reconhecimento (HONNET, 2003; BITTAR, 2009) -, as mulheres têm ocupado parte relevante do debate político e da agenda de pesquisa sobre as inequidades da representação. Logicamente, não se trata de minoria demográfica, já que constituem mais da metade da população - no Brasil, pelo menos. São, no entanto, minoria em termos de expressão política, tanto fora quanto dentro dos espaços decisórios institucionalizados.

À parte as polêmicas envolvendo as questões gerais relativas à representação das identidades de grupos e indivíduos privados de liberdade política ${ }^{2}$ (YOUNG, 2001; 2006; PHILLIPS, 2001), este artigo se

2. De um lado há os que, em convergência com movimentos sociais de minorias, apoiam ações afirmativas, soluções institucionais para proteção de grupos diversos, como forma de mitigação da exclusão política nos parlamentos, nos partidos políticos, nos processos eleitorais e noutros espaços e processos do poder; por outro, há os críticos a essa perspectiva, por seu pressuposto supostamente essencialista da identidade das minorias. Para os críticos, a ideia de identidade unifica artificialmente os grupos minoritários, compromete a liberdade e a autonomia subjetiva de indivíduos dos grupos sociais que são, na verdade, marcados pela complexidade e diversidade internas, como é a própria sociedade. Os críticos normativos defendem 
volta particularmente para o problema da exclusão das mulheres, dos obstáculos que enfrentam para participar dos espaços decisórios e das soluções que têm sido buscadas neste sentido.

Sem subestimar a importância dos movimentos de minorias e sua variada agenda de reinvindicações, visando e promovendo mudanças de valores e práticas sociais, a literatura pertinente tem posto em evidência as instituições politicas, vistas, por um lado, como causas da exclusão, por outro, como fontes potenciais de soluções. Os sistemas eleitorais e a estrutura interna das organizações partidárias são temas centrais na discussão, com particular e profícua contribuição de autores - em especial, autoras - aderidos à perspectiva neoinstitucionalista ou inspirados pela mesma..

0 compromisso com a democracia tem levado pesquisadores a sustentar, com teorias normativas e estudos empíricos, as demandas de grupos minoritários por soluções institucionais que assegurem cotas ou reserva de vagas nos processos de seleção de representantes.

Não obstante, a ênfase recente nas dinâmicas participativas, antielitistas, associadas às novas formas de mobilização social, às novas práticas governamentais e à criação de instituições que viabilizam a participação direta, as instituições representativas são tidas como indispensáveis. Destacam- se os partidos como instituições centrais do sistema, por seu forte poder de mobilização política, a despeito da crise das últimas décadas (MANIN, 1995; NOVARO, 1995; YOUNG, 2001; 2006; PATEMAN, 1992). 0 fato é que partidos ainda importam, por diversos motivos.

Young (2006) lembra que essas organizações são canais importantes na representação de opiniões, elaborando "programas que, menos [sic] que expressar os interesses de um determinado eleitorado, organizam os temas políticos do dia segundo princípios, valores e prioridades que eles se propõem a representar de forma geral" (YOUNG, 2006, p. 161).

Ademais, em grande parte das democracias, partidos detêm o monopólio da representação, não sendo possível alcançar cargos eletivos senão por meio deles. E mesmo onde tal monopólio é quebrado - em sistemas que, por exemplo, permitem candidaturas avulsas -, os partidos dominam o recrutamento e a formação de governantes. Vejam-se os casos do Chile e dos Estados Unidos. A Casa dos Representantes dos EUA não acolhe candidatos independentes há cinco legislaturas: a eleição do último candidato independente se deu em 2004 e, desde então, houve cinco eleições. No Chile, seis eleições ocorreram entre 1997 e 2017, e apenas 15 candidaturas independentes saíram vitoriosas, num total de 720

uma autonomia radical, para além dos grupos e de suas possibilidades de representação (BENHABIB, 1996; MOUFFE, 2003; PHILIPS, 2001). A contra-argumentação à crítica, no entanto, sustenta que há formas institucionais de fomento à participação politica das minorias que não bloqueiam as possibilidades de manifestação da individualidade no seio de uma comunidade (Pateman, 1992). Nessa discussão há ricas divergências - que não cabe discutir neste artigo - sobre concepções ontológicas da identidade e sobre as formas institucionais que permitiriam expressá-las. No entanto, elas têm em comum a defesa da participação ativa e autônoma dos cidadãos na vida pública. 
vagas disputadas - a Câmara chilena tem 120 cadeiras $^{3}$.

A estrutura da lista partidária, definida pelos partidos, também tem sido um dispositivo institucional bastante mencionado. Diversas democracias obrigam os partidos a reservarem vagas para determinada categoria social considerada politicamente excluída. As mulheres são, talvez, a minoria mais frequentemente considerada.

$\mathrm{Na}$ América Latina, 13 países adotam algum critério, compulsório ou voluntário, para assegurar a candidatura de mulheres (SPOHR, 2016, p. 425). Os modelos de reserva adotados, no entanto, não são os mesmos e causam diferentes impactos sobre a representação feminina. Brasil e Argentina são exemplos lapidares: aqui a norma prevê que 30\% dos nomes da lista devem ser para um dos sexos - isso, em princípio, favorece as mulheres que, antes, figuravam num percentual bem menor nas listas eleitorais. Mas, devido à adoção de lista aberta, o número de mulheres eleitas fica muito aquém desse percentual. Com as eleições de 2018, apenas 15,0\% das cadeiras na Câmara e $14,8 \%$ das cadeiras no Senado foram conquistadas mulheres; na Argentina, com eleições realizadas em 2017, os valores são, respectivamente, 38,9 e $41,7 \% 0^{4}$. Tais diferenças se devem, em grande parte, às normas ligadas à lista eleitoral e aos modelos de reserva.

Em ambos os países vigem eleições proporcionais para a Câmara e majoritárias para o Senado, mas divergem em outros aspectos do sistema. Na Argentina, desde 1991, a legislação determina que no mínimo 30\% das vagas nas listas partidárias seja para mulheres, devendo-se alternar os homens e mulheres na ordenação das listas. Como a lista é fechada, não é possível ao eleitor manifestar sua preferência pessoal por candidaturas à Câmara, mas por partidos (MATOS, CIPRIANO E BRITO, 2007; SPOHR et al., 2016). No caso do Senado argentino, a obrigatoriedade da indicação de mulheres aumenta suas chances de se fazerem representar. No Brasil, a lista aberta permite aos indivíduos escolher nomes, não só partidos, reduzindo as chances do sucesso eleitoral feminino. A tendência dos eleitores a escolherem candidatos masculinos se explica, em grau importante, pela exclusão histórica decorrente de velhos preconceitos e discriminação - algo como: “o lugar das mulheres não é na política”.

0 fato é que - a despeito de variações institucionais entre um país e outro - os partidos dominam a representação, o que faz das organizações partidárias arenas estratégicas de disputa, nas quais as mulheres ainda enfrentam obstáculos severos para uma atuação valorizada. Isso, porém, varia com os partidos, devido a fatores como a racionalização da estrutura organizacional, a institucionalização, a profissionalização e a ideologia. Estudos sobre o recrutamento de candidatas no Brasil mostram que as políticas e dinâmicas internas aos partidos são decisivas para a ascensão política das mulheres à Câmara dos Deputados (COS-

3. Dados obtidos em http://www.ipu.org/parline-e/parlinesearch.asp, disponivel em 17.01.2019.

4. Dados extraídos de http://www.ipu.org/wmn-e/classif.htm. Disponível em 17.01.2019. 
TA; BOLOGNESI; CODATO, 2015; ARAÚJO, 2005; 2009).

Entra aqui outro aspecto institucional importante: a forma como os partidos se organizam internamente e como enfrentam o problema da representação de mulheres e de outros segmentos politicamente minoritários. Vários estudos sustentam que, sem medidas afirmativas formais e práticas de empoderamento das minorias no interior das estruturas partidárias, as variáveis estruturais e institucionais externas - defesa de valores democráticos, normas constitucionais e infraconstitucionais - tendem a perder efeito (NORRIS, 2013; ARAÚJO, 2005). Entende-se que a ocupação de funções de poder na estrutura das organizações partidárias daria às mulheres oportunidades para influenciar a distribuição dos recursos financeiros, organizacionais e logísticos dos partidos de forma mais equânime entre os diversos segmentos que compõem o corpo de filiados (NORRIS, 2013; ARAÚJ0, 2005).

Clara Araújo (2005) sintetiza a literatura e apresenta conclusões extraídas de entrevistas realizadas com parlamentares, candidatos não eleitos, dirigentes, representantes de núcleos de mulheres dos partidos PP, PFL/DEM, PMDB, PDT e PT. A autora avaliou o processo de incorporação das cotas pelos partidos citados com base em entrevistas (com seus dirigentes, representantes de núcleos de mulheres, parlamentares, candidatos não eleitos) e em documentos das organizações partidárias, como cartilhas produzidas pelos movimentos de mulheres, além dos regimentos e programas partidários (ARAÚJO, 2005). A pesquisa observou a incipiência das medidas afirmativas e a permanência de obstáculos, tanto sociais, quanto institucionais. Conforme a autora, as entrevistas expuseram o reconhecimento da importância dos partidos, bem como críticas por boa parte dos agentes partidários ao funcionamento das instâncias internas das organizações partidárias. Posições diferentes foram expressas pelos entrevistados que compunham diretórios regionais ou instâncias importantes do partido. Tais membros demonstraram afınação com a dinâmica e as decisões partidárias, indicando que aquelas e aqueles que se vêem capazes de influenciar o rumo do partido por meio da ocupação de posições estratégicas na organização se mostram mais aderidos aos projetos partidários.

Convergentemente, em estudo de Costa, Bolognesi e Codato (2015), percebeu-se uma interação das orientações ideológicas com as características organizacionais na configuração de práticas e normas formais para elevar mulheres à ocupação de cargos na estrutura partidária. 0 estudo mostrou que partidos de esquerda são mais empenhados em promover seu segmento feminino. A esquerda se destaca em relação aos demais blocos pela prestação de serviços de creche em eventos especiais do partido; pela adoção de cotas na ocupação de cargos partidários; pela inclusão de um percentual maior de mulheres (com maiores qualificações para a política), o que resulta em maior capacidade feminina para alçar candidatas a cargos eletivos.

Mas a adoção de certas medidas internas, como a criação de cotas ou órgãos voltados a mulheres e o percentual de mulheres na lista não implica necessária melhoria nas condições de participação política (MIGUEL, 2008): é necessário empoderamento feminino objetivo. Dispositivos ou órgãos formais devem ter implicação na vida prática dos partidos e seus integrantes. Em relação a cotas para ocupação de cargos no interior das estruturas partidárias, é preciso 
que os cargos alocados a mulheres tenham real influência sobre as decisões e estratégias das legendas. A simples reserva de cotas nas listas eleitorais também não é suficiente. Como exemplo, pode-se lembrar que a lei eleitoral brasileira de 1997 estabelecia a obrigatoriedade de reservar um mínimo de $30 \%$ das vagas na lista para um dos sexos; em 2009, uma alteração tornou obrigatório o preenchimento de um mínimo de $30 \%$ das vagas com candidatos de um dos sexos, substituindo o termo "reservar" por "preencher”. O resultado da alteração, se, por um lado, obrigou os partidos brasileiros a nomear maior percentual de candidatas que o anteriormente praticado, por outro, deu-se um preenchimento forçado, com candidaturas femininas protocolares, cujas pleiteantes dispunham de pouquíssimo ou nenhum apoio de suas legendas. De acordo com dados do TSE5 , nas eleições de 2006, anteriores à mudança legal, o percentual de mulheres eleitas foi de 7,05\% (46 de 652 candidatas); em 2014, última eleição, apenas 2,84\% de candidaturas femininas obteve sucesso (51 de 1796). Os números mostram que o contingente feminino recebeu cinco deputadas a mais em 2014, mas apontam, em contrapartida, o desperdício de energia de muitas mulheres em disputas fadadas ao fracasso eleitoral, pelo desprovimento de recursos politicamente estratégicos.

0 comprometimento dos partidos é fundamental, ou não se alcançam os resulta- dos almejados. Na experiência brasileira, o mero aumento artificial das legislaturas fez crescer o percentual de candidatas não competitivas e, em parte por isso, tendem a se desinteressar pela política partidária. Para ser atraente, a participação precisa ser sentida como relevante por quem se dispõe inicialmente a participar. Do contrário, tenderá a haver frustração, perda de interesse e evasão dos partidos e da própria política (PATEMAN, 1992; ARAÚJO, 2005).

0 fato é que estratégias de apoio à igualdade entre os sexos têm o efeito de instigar a participação partidária institucionalizada e incentivar a profissionalização parlamentar feminina. Segundo Costa, Bolognesi e Codato (2015), determinados padrões de apoio organizacional tendem a um círculo virtuoso, no qual sucessos eleitorais decorrentes dos investimentos partidários estimulam o interesse das mulheres pela política, reforçam suas capacidades (no sentido de SEN, 2010) para as contendas democráticas, fomentando a consolidação da atividade política como profissão também de mulheres. A profissionalização expressar-se-ia, entre outras formas, no acúmulo gradativo e consistente de experiência em cargos políticos eletivos e não eletivos, na dedicação sistemática às funções políticas legislativas ou executivas e na reiteração das posições de poder político. ${ }^{6}$

Para os críticos do elitismo, a profissionalização e a institucionalização dos polí-

5. Dados extraídos de www.tse.jus.br, disponível em 16.06.2017.

6. Essa conclusão não está na obra dos autores citados, mas é notório o interesse de parlamentares no Brasil em ocupar postos na administração pública e disputar cargos executivos nos municipios e nos estdos (Ames, 2000; Araújo, 2009). É o caso, com base nos dados adiante analisados neste artigo, de verificar se a trajetória política das mulheres indica padrão similar. 
ticos e das estruturas políticas expressam aspectos negativos da racionalização da política. São fenômenos associados ao distanciamento dos representantes frente aos cidadãos e degradam a representação: têm o efeito de consolidar a hegemonia de homens brancos no poder e afastar da política segmentos expressivos da sociedade, prejudicando os indivíduos e as minorias historicamente excluídas. Um dos resultados negativos seria a depreciação das interações e trocas entre cidadãos e representantes, que devem ou deveriam se dar durante os mandatos, e não apenas nos momentos eleitorais (YOUNG, 2001, 2006; URBINATI, 2006; MANIN; PRZEWORSKI; STOKES, 2006). Daí a ênfase contemporânea em instituições e processos, como cotas, reserva de vagas nas listas, democratização da distribuição dos cargos partidários para mulheres e outras minorias, com vistas a reverter ou mitigar os efeitos da elitização.

Mas, a despeito das críticas, é virtualmente consenso que a profissionalização é necessária e torna-se forçosa, de modo a propiciar o acúmulo de habilidades e conhecimento necessários - embora não suficientes - ao bom desempenho político, particularmente no âmbito parlamentar. A alocação de cargos para mulheres em postos da organização partidária, por exemplo, é importante para a inclusão feminina na medida em que suas posições na organização partidária se consolidam, permitindo que elas dediquem mais tempo à atividade política e tenham mais oportunidades para se qualificarem e se profissionalizarem. Assim elas poderão atuar de forma mais efetiva no interior de estruturas complexas e multifuncionais como os partidos modernos.

Ainda mais relevante seria, portanto, a profissionalização para a atuação par- lamentar. Lembrando Pitkin (1983, 2006), o importante não é apenas quem os representantes são - no caso, mulheres -, mas o que fazem. Para fazerem bem, precisam ser qualificadas ou buscar desenvolver experiências e habilidades para desempenhar funções cada vez mais complexas no âmbito das organizações legislativas, executivas ou administrativas, conforme as aspirações autoestabelecidas. Assim, não só atributos de background social, como sexo, cor, classe, religião, escolaridade, profissão pregressa e status social são importantes. Também importam o conhecimento e as experiências que os representantes são capazes de acumular na vida política e o que são capazes de fazer no âmbito do poder por aqueles a quem devem atender.

Nesse sentido, quanto mais profissionalismo, melhor, desde que isso não incorra nos efeitos reversos, elitistas, tão fortemente criticados. A profissionalização se torna particularmente estratégica no caso das mulheres, que, no bojo das culturas tradicionais, patriarcais e discriminatórias, têm mais do que os homens suas habilidades sujeitas a desconfiança.

A demonstração de qualificação pode ser uma forma de desfazer preconceitos e mostrar que o sexo não carrega em si propensões profissionais ou potencialidades de desempenho, a não ser em função dos obstáculos e exigências socialmente impostos às mulheres e outras minorias, que as impedem de fazer o que pretendem ou poderiam pretender. No caso das mulheres, a divisão doméstica do trabalho é uma grave comprovação disso. Elas costumam ser cobradas pelos cuidados com a casa e com os filhos, e tendem a usar parte do tempo e da energia no desempenho dessa função (o chamado terceiro turno). Isso explica a importância de subsídios e outras formas 
de apoio - como creches - dentro dos partidos, nos parlamentos, em órgãos da administração pública. Eles liberam tempo e energia das mulheres para a política.

A crescente competividade da política nas democracias está relacionada à racionalização e à institucionalização do campo político como palco de profissões (PERISSINOTO; BOLOGNESI; 2015; COSTA; CODATO, 2015; MARENCO, 1998). Eleições, por exemplo, mobilizam intensamente os partidos e seus filiados e envolvem profissionais de todos os tipos: publicitários, contadores, jornalistas, fotógrafos, especialistas em logística, captadores de financiamento, administradores e outros (vide WEBER, 1974).

Logicamente, esse esforço visa a alcançar objetivos partidários essenciais: a eleição de representantes e a ocupação de cargos na estrutura do Estado, dos quais se espera extrair recursos e influenciar políticas públicas (KATZ; MAIR, 1992; MENEGELLO, 2003). Os agentes centrais, para os quais se volta toda mobilização organizacional, são os representantes dos partidos nos cargos de poder, bem como aqueles e aquelas que os líderes avaliam com potencial para sê-lo. Eles e elas precisam demonstrar habilidades e vocação para praticar a política como profissão e, assim, serem atraentes para as lideranças partidárias.
No caso das mulheres, precisam se desdobrar para superar os obstáculos adicionais, mas não podem ser alheias à necessidade de profissionalização, se pretendem sobreviver às disputas políticas. Enfim, elas, tal qual os homens, precisam não apenas viver $d a$ política, mas para a política $^{7}$ - evocando a memorável expressão de Weber (1974). Sendo assim, é importante dar-se, dedicar-se séria e sistematicamente ao mundo político, é preciso profissionalizar-se. Não por acaso, no Brasil, nas opções para indicação de profissões no cadastro das candidaturas, foi incluída a alternativa "político".

Coletânea organizada por Codato, Costa e Máximo (2015) reúne um conjunto de artigos que induzem à conclusão de que no Brasil, como no mundo democrático, a política caminha para a profissionalização. Um indicador central mobilizado nos estudos contidos na obra são as taxas altas e crescentes de sucesso dos candidatos que declaram, ao TSE, serem profissionais da política - em especial candidatos à Câmara dos Deputados. São taxas de sucesso superiores às de qualquer outra profissão declarada pelos candidatos. A ideia, como acima manifesta, é que o profissional típico se dedica à política com tempo e outros recursos que aumentam seu know-how e

7. 0 sentido dado por Weber ao "viver da política” evoca outra dimensão da representação, que não será trabalhada neste artigo devido aos limites dos dados disponiveis. Essa outra dimensão é referente às condições de vida que o exercício profissional pode assegurar a quem se dedica a tal atividade, em qualquer instância ou instituição: nível salarial, condições de trabalho, proteção a saúde, previdência social e proteção à família - benefícios que, em tese, são menos importantes para as elites históricas e cruciais para atrair minorias desprovidas de recursos para a escolha da política como profissão (vide SQUIRE, 1988). 
sua eficiência como representante e como competidor eleitoral, assumindo a atividade de maneira exclusiva e permanente. Não sem razão, as profissões mais favoráveis à produção de políticos profissionais são as que disponibilizam mais tempo aos indivíduos para se engajarem na política e nos partidos - é o caso do Direito, conforme mencionado por Weber (1974).

Está claro que tais conclusões contrariam a visão negativa de que os partidos brasileiros são pouco institucionalizados e desimportantes, de que os representantes não se profissionalizam e de que as eleições são marcadas por outsiders aventureiros, que concorrem por oportunismo e vencem eleições (CODATO; COSTA; MÁXIMO, 2015). Essa é mais uma base de confirmação de que a atuação política das mulheres precisa mobilizar os partidos em suas estratégias de ascensão a cargos representativos.

Afinal, no Brasil, qual o perfil social das mulheres atuantes no parlamento federal e que experiências políticas elas obtêm antes de chegar a estes altos cargos de representação política? Em que medida os dados apontam para a qualificação ou mesmo para a profissionalização política feminina? Em que medida e em que aspectos elas se distanciam ou se aproximam dos homens que ocupam as mesmas posições? A partir dos argumentos e questões acima colocados, o tópico seguinte apresenta uma análise comparada de deputadas e deputados federais, visando a mostrar indicadores empíricos dos efeitos da realidade vivida pelas mulheres sobre o perfil e as trajetórias das recrutadas para a Câmara dos Deputados no Brasil.

\section{Gênero e perfis sociais de parlamentares do Congresso Nacional}

Dos argumentos acima expostos pode-se extrair, em síntese, que toda a luta pela inclusão das mulheres não terá efeito significativo sem condições e disposições para a profissionalização política. A profıssionalização, conforme aqui entendida, é o processo por meio do qual representantes passam a dedicar tempo e outros recursos em busca da qualificação para a função de representar (POLSBY, 1968). Aquelas e aqueles que querem ser profissionais da política se esforçam para se manter no poder e se comprometem com as atividades político-partidárias.

Os dados aqui disponíveis não permitem uma análise sistemática da profıssionalização no Congresso Nacional, mas oferecem indicadores indiretos do interesse das e dos congressistas em permanecer na vida política, do leque de experiências acumuladas ao longo da carreira política e do sucesso profissional, sucesso este avaliado em termos do tempo de atuação no parlamento, da abrangência e variedade das experiências parlamentares, bem como do leque de experiências em outros postos eletivos e não eletivos ofertados pela estrutura federativa do Estado brasileiro.

A análise começa pela apresentação de dados sobre o background social dos e das parlamentares para revelar em que bases se construíram suas trajetórias rumo ao Congresso Nacional.

0 gráfico 1 confirma o que os estudos já identificaram, mas não com o recorte temporal ou a abrangência aqui apresentados (vide SIMONI JR., MUSSINHATO; MINGARDI, 2015; MUSSINHATO, 2014). A presença percentual de mulheres é baixa, revelando-se uma ascensão leve, mas con- 
sistente, ao longo do período. A desigualdade entre mulheres e homens que marca a distribuição das cadeiras se confırma, mas a linha de tendência para cima permite a hipótese de que as mudanças sociais nos valores, os incentivos institucionais internos e externos aos partidos e a intensificação da mobilização feminina têm produzido resultados positivos para a representação das mulheres. A média de representação feminina no conjunto das oito legislaturas consideradas foi de 6\%, ainda muito baixo. 0 percentual mundial é de $22,9 \%$, e na América do Sul é de 25,9\% $\%^{8}$. Atualmente, o Brasil ocupa o $131^{\circ}$ lugar no ranking dos sistemas representativos do mundo ${ }^{9}$.

Gráfico 1. Representação de mulheres e homens por legislatura (\%)

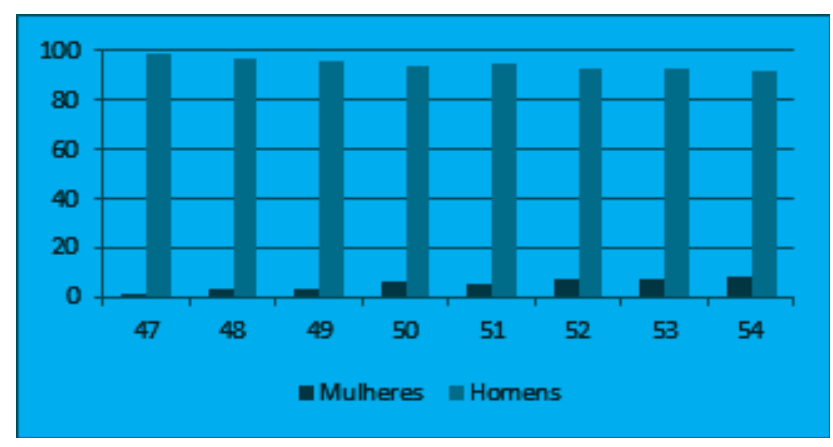

Fonte: elaboração própria, com base em dados dos sites do Senado Federal e da Câmara dos Deputados.

Quanto à origem regional das parlamentares, o Norte se mostra a região mais favorável à representação feminina, pois $9,1 \%$ dos mandatos dessa região foram exercidos por mulheres. 0 índice de representação do Norte vai contra a intuição de que regiões mais industrializadas e plurais favorecem mais as mulheres como minorias políticas. Não se pode explicar a força das nortistas pelo grau de modernização social e pelo cosmopolitismo da região, mas, talvez, pelo impacto de casos individuais na configuração do contingente parlamentar. A diferença se dá, em grande parte, pelo desempenho eleitoral das acreanas.
No período, oito mulheres do Acre passaram pelo Congresso, sendo duas no Senado e seis na Câmara. Algumas delas passaram por mais de uma legislatura. Entre as deputadas, Celia Mendes e Adelaide Neres, (PMDB) tiveram dois mandatos cada; Zila Bezerra (PTB), três; Perpétua Almeida do $\mathrm{PCdoB}$, quatro, e atualmente está no quinto mandato. No Senado, Marina Silva foi reeleita e atuou em três legislaturas sucessivas, já que os mandatos senatoriais são de oito anos e cobrem duas legislaturas. Em 2002, ela se licenciou do cargo, para assumir o Ministério do Meio Ambiente - sua cadeira foi assumida pelo suplente Sibá Machado.

8. Os dados de todos os gráficos e tabelas foram extraídos dos sites do Senado Federal e da Câmara dos Deputados, coletados ao longo dos anos e revisados em 2017. Todos os gráficos e tabelas foram elaborados pelo autor. 9. Dados obtidos em http://archive.ipu.org/wmn-e/classif.htm, disponível em 17.01.2019. 
Tabela 1: Distribuição (\%) de mandatos femininos por região e legislatura

\begin{tabular}{|l|r|r|r|r|r|r|r|r|r|}
\hline & Leg. 47 & Leg. 48 & Leg. 49 & Leg. 50 & Leg. 51 & Leg. 52 & Leg. 53 & Leg. 54 & Média \\
\hline Centro-0este & 0,0 & 2,9 & 7,7 & 10,1 & 11,1 & 11,1 & 4,1 & 8,0 & 7,1 \\
\hline Nordeste & 1,0 & 3,7 & 1,1 & 0,5 & 1,0 & 3,7 & 4,7 & 5,3 & 2,6 \\
\hline Norte & 2,2 & 6,2 & 5,4 & 10,8 & 9,7 & 9,5 & 13,2 & 12,2 & 9,1 \\
\hline Sudeste & 2,7 & 3,7 & 5,7 & 8,5 & 6,6 & 8,1 & 8,5 & 9,2 & 6,7 \\
\hline Sul & 0,0 & 2,0 & 1,8 & 2,7 & 3,4 & 7,6 & 7,8 & 8,1 & 4,2 \\
\hline
\end{tabular}

Fonte: elaboração própria, com base em dados dos sites do Senado federal e da Câmara dos Deputados.

Na tabela, o Sudeste, região mais industrializada, aparece em segundo lugar, com média de 6,7\% de mulheres por legislatura. 0 Nordeste é a região que menos favorece a representação de mulheres. No período, a bancada de mulheres nordestinas no Congresso é de apenas 2,6\% em relação ao total da bancada da região. De toda forma, no Nordeste, como em todas as demais regiões - exceto o Centro-Oeste -, nota-se uma tendência de aumento percentual da representação feminina ao longo do tempo.
No tocante à idade das parlamentares, os dados mostram uma tendência de alta, com média de 47,7 anos para mulheres e 50,7 para homens. No intervalo abarcado, a média de idade das mulheres aumentou 8,1 pontos percentuais e dos homens, 3,4 pontos. Nota-se que, ao longo do tempo, as idades de mulheres e homens foram se aproximando, com curva ascendente mais acentuada para as mulheres, até se encontrarem no final do período.

Gráfico 2: Média de idade por sexo e legislatura

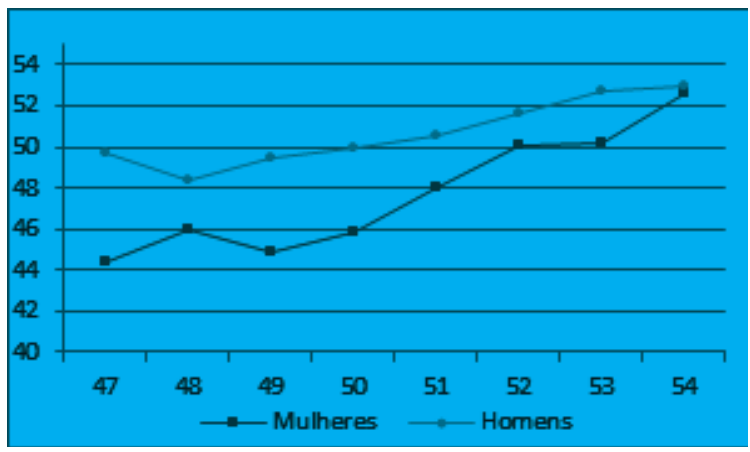

Fonte: elaboração própria, com base em dados dos sites do Senado federal e da Câmara dos Deputados.

Esse fenômeno permite leituras dúbias sobre o perfil político das mulheres: por um lado, pode expressar maior dificuldade delas para alcançar altas posições no poder político; por outro, o fato de ocuparem mandatos com idade cada vez mais elevada pode significar um aumento da experiência prévia até chegar ao nível mais alto da representação parlamentar no país. Outra possibilidade positiva de interpretação é que o aumento na média de idade pode refletir o sucesso das mulheres em permanecer em cadeiras congressuais por mais tempo - vale lembrar aqui que a unidade de análise são mandatos, não indivíduos, de modo que aquelas e aqueles que perma- 
necem na cadeira por mandatos sucessivos envelhecem nos mandatos e aumentam a média geral de idade nas legislaturas. 0 fato de a média de idade das mulheres ascender mais rápido pode indicar que elas vêm elevando seus níveis de experiência e obtendo maior consolidação profissional mais rapidamente do que os homens.

A escolaridade é um atributo fundamental de legisladoras e legisladores para a lida cotidiana com temas complexos, e também tem peso expressivo no próprio processo de recrutamento.

Tabela 2: Nível de escolaridade por sexo e legislatura (\%)

\begin{tabular}{|l|l|r|r|r|r|r|r|r|r|r|}
\hline Sexo & $\begin{array}{l}\text { Nivel de } \\
\text { escolaridade }\end{array}$ & Leg. 47 & Leg. 48 & Leg. 49 & Leg. 50 & Leg. 51 & Leg. 52 & Leg. 53 & Leg. 54 & Média \\
\hline Mulheres & $\begin{array}{l}\text { Ensino } \\
\text { fundamental ou } \\
\text { menos }\end{array}$ & 0,0 & 0,0 & 0,0 & 2,2 & 0,0 & 7,3 & 0,0 & 0,0 & 1,5 \\
\cline { 2 - 10 } & $\begin{array}{l}\text { Ensino médio } \\
\text { completo }\end{array}$ & 10,0 & 11,5 & 20,7 & 13,0 & 9,3 & 16,4 & 17,2 & 14,5 & 14,6 \\
\cline { 2 - 9 } & $\begin{array}{l}\text { Ensino Superior } \\
\text { completo }\end{array}$ & 90,0 & 88,5 & 79,3 & 84,8 & 90,7 & 76,4 & 82,8 & 85,5 & 83,9 \\
\hline Homens & $\begin{array}{l}\text { Ensino } \\
\text { fundamental ou } \\
\text { menos }\end{array}$ & 1,6 & 1,2 & 2,0 & 1,8 & 2,1 & 3,8 & 2,4 & 2,2 & 2,2 \\
\cline { 2 - 9 } & $\begin{array}{l}\text { Ensino médio } \\
\text { completo }\end{array}$ & 5,7 & 7,7 & 14,1 & 16,5 & 16,2 & 16,3 & 13,9 & 16,9 & 13,5 \\
\cline { 2 - 9 } & $\begin{array}{l}\text { Ensino Superior } \\
\text { completo }\end{array}$ & 92,7 & 91,1 & 83,8 & 81,7 & 81,7 & 79,9 & 83,7 & 80,9 & 84,3 \\
\hline
\end{tabular}

Fonte: elaboração própria, com base em dados dos sites do Senado federal e da Câmara dos Deputados.

No Brasil, analfabetos são impedidos de se candidatar, podem apenas votar. Para se candidatar, é preciso no mínimo saber ler e escrever. Mas pessoas com baixa escolaridade têm, em geral, baixa renda e baixo status social, são discriminados e socialmente desprestigiados. Eles compartilham dos problemas de várias outras minorias. Para a vida política, os pontos de corte são postos já nas candidaturas, pelos partidos, ou nas eleições, pelos votantes. As chances dos pouco escolarizados chegarem a cargos de poder, particularmente no nível federal, são muito baixas - embora haja exceções, como no caso notório do comediante Tiririca, eleito em 2010 e em 2014. 0 fato é que a escolaridade é um recurso estratégico na triagem para os níveis de poder político. No
Congresso, a escolaridade é alta para ambos os sexos, com média geral similar para mulheres e homens: elas, 83,9; eles, 84,3. No Parlamento Federal, como na sociedade brasileira, as mulheres têm alcançado graus de escolaridade igual ou superior aos dos homens.

A formação acadêmica permite aos eleitores e eleitoras saberem quem seus representantes são - nos termos da dimensão descritiva do representar, evocado por Pitkin $(1983$; 2006). Os campos de formação acadêmica apontam, para além dos níveis educação formal, a qualificação dos e das parlamentares para se engajarem no debate e na aprovação de leis referentes a temas relevantes da vida social.

Ademais, formações acadêmicas e profıs- 
sões se influenciam mutuamente. Educação formal orienta as escolhas profissionais de muitas pessoas. E o inverso também ocorre: práticas profissionais induzem as pessoas a escolherem seus cursos universitários. 0 fato é que formação e profissão estão relacionadas $^{10}$. Algumas profissões/formações são mais afeitas à política, seja pela forma como os indivíduos podem controlar seu tempo de atuação profissional para se disponibilizarem para o jogo político, seja pelo cabedal adquirido na formação, que qualifica os representantes para as discussões políticas ou para a atuação eficiente nos processos decisórios (CODATO; COSTA; MASSIMO, 2015; WEBER, 1974; BEST; COTTA, 2000). No primeiro caso, pode-se mencionar a Economia; no segundo, o Direito.

Gráfico 3 - Ciências médicas e da saúde (\%)

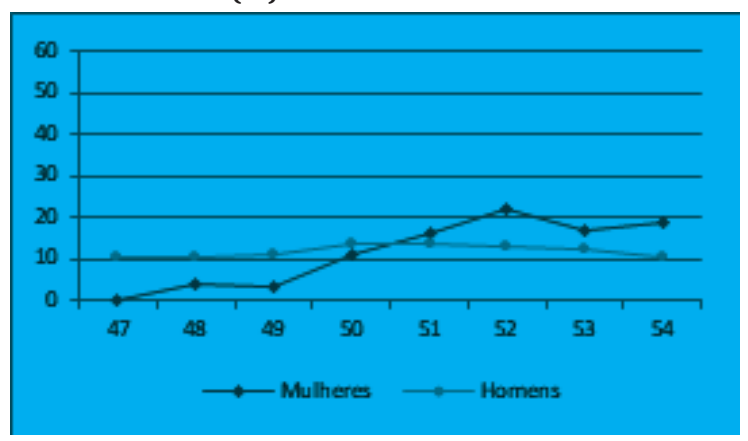

Gráfico 4 - Artes e Humanidades (\%)

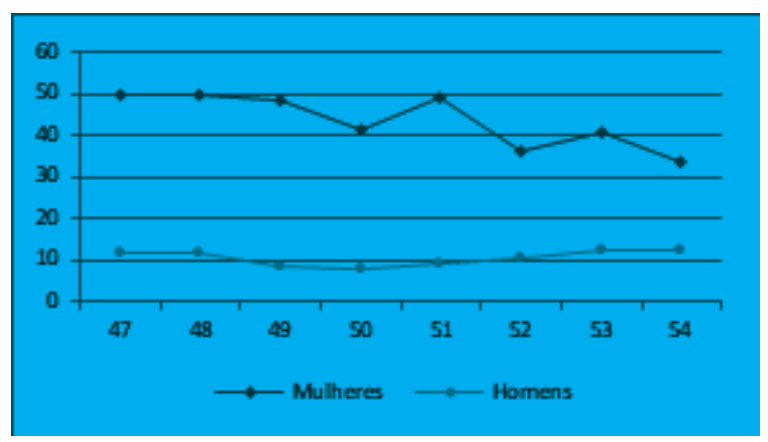

10. As profissões não serão avaliadas neste artigo devido às imprecisões das informações nas fontes de dados consultadas. Para ficar apenas em um exemplo: parlamentares com diploma em Direito frequentemente afirmam ser advogados, quando, em verdade, nunca atuaram na área. A formação acadêmica não permite dubiedades, já que é formalmente atestada pelo diploma (para uma maior explanação dos dilemas enfrentados nessa questão metodológica, sugere-se: Perissinotto e Codato. Como estudar elites. Curitiba: UFPR, 2015). 
Gráfico 5 - Engenharias (\%)

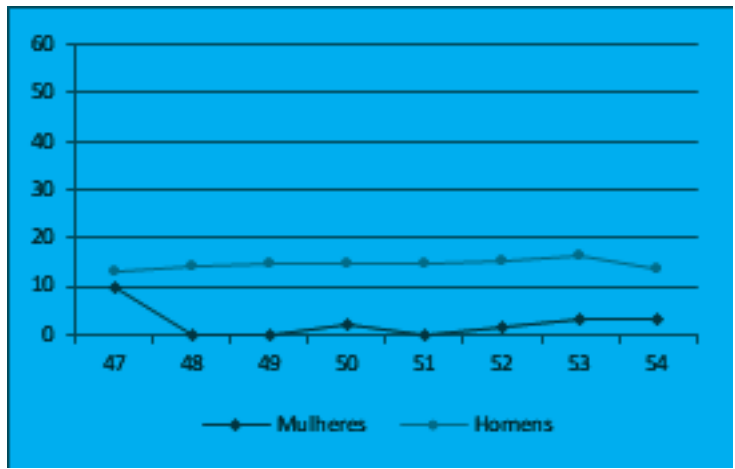

Gráfico 6 - Direito (\%)

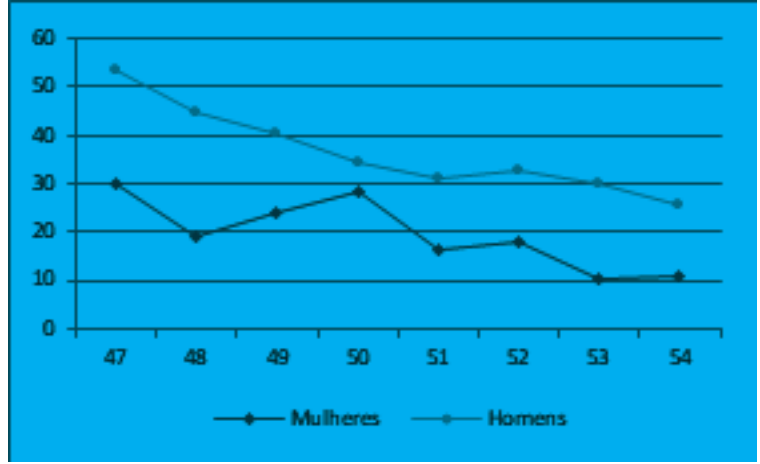

Gráfico 7 - Ciências econômicas (\%)

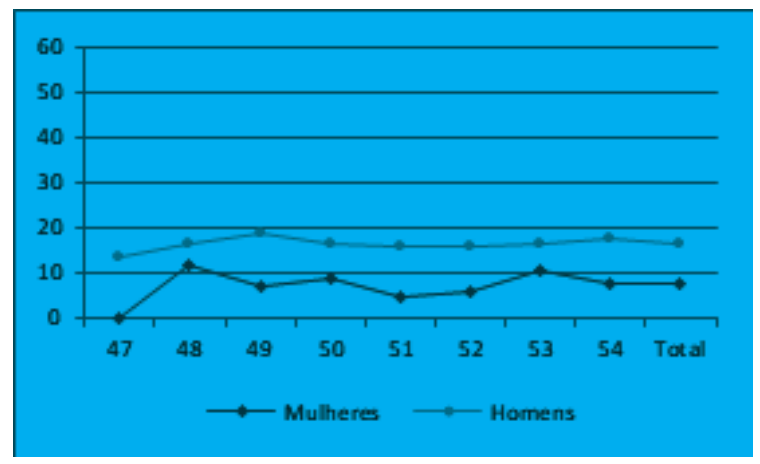

Fonte: elaboração própria, com base em dados dos sites do Senado federal e da Câmara dos Deputados.

Os gráficos 3 a 7 resultam da agregação das dezenas de campos em que os congressistas se diplomaram, de modo a permitir uma análise parcimoniosa dos dados. De início, nota-se, como esperado, a relação entre sexo e formação acadêmica. Segundo Barbosa (2007), a procura pelos cursos de Direito e Economia ainda é mais comum entre os homens. Já Araújo e Borges (2013) identificaram que saúde e educação são temas preferidos pelas mulheres. Barbosa, citando Galisa (2005), afirma que dados do CNPq revelam uma preferência maior das mulheres por cursos nas áreas de ciências 
humanas, ciências sociais e ciências sociais aplicadas, Linguística, Letras e Artes, enquanto os homens tendem fortemente para a área de exatas (BARBOSA, 2007, p. 29).

Fenômeno similar se observa entre os e as representantes no Congresso Nacional. Os gráficos sugerem que a busca por formação acadêmica tende a ser afetada pela posição dos indivíduos na estrutura social: isso pode expressar certo condicionamento social das mulheres que escolhem a política como profissão. Os condicionantes sociais que afetam a busca por diplomas se refletem também no âmbito de organizações como os partidos e os parlamentos ${ }^{11}$, limitando potencialidades insuspeitas que poderiam se revelar num contexto de ampla liberdade das mulheres para fazerem suas escolhas.

Resumindo o tópico: os dados gerais de background social das parlamentares do Congresso Nacional revelam que as mulheres dispõem de atributos sociais estratégicos para trilhar os caminhos do poder.
Mas pode-se dizer que o exercício da representação pelas mulheres ainda guarda relações com o que se diz serem de "coisas de mulher". Isso revela consequências do patriarcalismo na cultura em geral e na política em particular, que tende a associar as mulheres às atividades atinentes ao "cuidado" e à vida doméstica, e os homens às atividades relativas à esfera pública ${ }^{12}$.

Pelo lado positivo, os dados revelaram um alto grau de aprendizado profissional formal, comprovado por diplomas universitários obtidos pelas mulheres - um nível de formação igual ao dos homens, na média do período.

Com relação à idade, comprovou-se que mulheres são mais novas, embora a curva ascendente no gráfico 2 mostre que elas se nivelaram aos homens na última legislatura do período considerado. Conforme dito, não há segurança para uma interpretação definitiva do envelhecimento das mulheres parlamentares, pois ele pode sinalizar coisas distintas. De um lado, pode indicar

11. As comissões legislativas que operam no interior das casas do parlamento são um exemplo expressivo dos efeitos de fatores sociais sobre a atuação política de mulheres e homens. Estudo de Araújo (2012) sobre a composição das comissões permanentes do Senado Federal mostra que a probabilidade de senadores homens ocuparem as comissões de Assuntos Econômicos e de Constituição e Justiça é positiva, ocorrendo, logicamente, o inverso para as senadoras. Já em relação à composição da Comissão de Assuntos Sociais, é mais provável que as lideranças indiquem mulheres. 0 mesmo estudo mostra que a composição das comissões é fortemente influenciada pela formação acadêmica dos e das parlamentares - advogados tendem a ser indicados para a Comissão de Constituição e Justiça, economistas, para a Comissão de Assuntos Econômicos; a Comissão de Assuntos Sociais tende a ser composta por parlamentares formados na área de Humanidades e assim por diante. Isso posto, ficam claros os efeitos da formação acadêmica sobre o exercício da representação por homens e mulheres (ARAÚJ0, 2012).

12. Há uma importante literatura sobre o patriarcalismo nas sociedades liberais, sobre suas implicações na problemática dicotomia público/privado e suas consequências sobre a estrutura das relações de gênero nas diversas instâncias da vida social. Essa discussão, porém, vai além do foco desse trabalho. Para mais, conferir Pateman (1996) e Okin (2008). 
maior acúmulo pregresso de experiência em outros cargos e melhor treino profissional das mulheres, adquiridos em trajetórias políticas mais longas; de outro, pode expressar dificuldades crescentes, decorrentes do aumento da competitividade eleitoral e da falta de apoio dos partidos, que fazem tardar a chegada das mulheres nos cargos políticos mais altos da federação. Neste ponto, as conclusões, a rigor, não são conclusivas, mas os dados avaliados no tópico seguinte jogam alguma luz nessa discussão.

\section{Gênero e trajetória política de parlamentares do Congresso Nacional}

É dispensável afırmar que a experiência prévia é uma variável fundamental para as chances de vencer eleições para o legislativo federal. Representantes que sobem na escada dos cargos públicos degrau por degrau se familiarizam com o jogo institucionalizado do poder e se qualificam gradativamente para atuação em níveis mais altos.
No entanto, parte das discussões atuais sobre recrutamento político têm abordado um fenômeno na contramão dessa expectativa: os outsiders.

Outsiders são figuras que, por dominarem recursos facilmente conversíveis em capital político, ingressam repentinamente na política e ocupam lugares altos, sem passar por arenas decisórias nos níveis inferiores de poder e, às vezes, sem terem experimentado qualquer prática política em atividades ou organizações sociais. ${ }^{13}$

A posse de grande patrimônio, a fama e os laços familiares são alguns dos fatores que podem promover os outsiders (MARENCO, 1997; MARENCO; SERNA, 2007). Pela trajetória, logicamente, não são profissionais da política, dada sua entrada intempestiva e, muitas vezes, circunstanciais e com data de término marcada.

Sobre isso, o que dizer do perfil das mulheres em relação a sua trajetória? São outsiders ou revelam um percurso político cumulativo e consistente, apontando na di-

13. É o caso dos suplentes de Senadores que financiam campanhas dos titulares e acabam por ocupar o mandato em algum momento. Vale citar trecho de matéria da revista Veja, de 26 maio 2013: "0 suplente Ataídes Oliveira (PSDB-T0) [...] destinou 305.000 reais para o comitê financeiro do Partido da República (PR), legenda do titular da vaga - e temporariamente afastado - João Ribeiro (PR-TO). Com a promessa de um dia chegar à cadeira do Senado, o suplente Francisco Simeão Rodrigues Neto doou para a campanha do senador paranaense Roberto Requião mais de 857.000 reais. 0 empresário Raimundo Lira, suplente do paraibano Vital do Rego, também fez doações do titular da vaga: 870.000 reais declarados. [...] Além das generosas doações para o caixa de campanha, outra prática recorrente é a nomeação de parentes para a suplência, situação que, ao contrário do nepotismo, é permitida pela lei brasileira. Um dos principais exemplos é Lobão Filho (PMDB-MA), herdeiro da cadeira do pai, o ministro Edison Lobão (Minas e Energia). [...] Já Ivo Cassol (PP-R0) fez diferente: nomeou o pai como seu substituto. Reditario Cassol, do mesmo partido, teve seus minutos de fama durante os três meses que passou no Senado [...]. Revista Veja: Suplentes: a (boa) vida dos senadores sem voto. Disponivel em http://veja.abril.com.br/politica/suplentes-a-boa-vida-dos-senadores-sem-voto/. Acesso em 12.06.2017. 
reção da profissionalização? Têm carreiras consolidadas quando chegam ao Congresso? Algumas informações a respeito são mostradas a partir do gráfico 8 .

Antes de avaliar a passagem das congressistas pelos cargos decisórios, eletivos e não eletivos, vale apresentar um dado importante: a distribuição ideológica das parlamentares do período. A filiação partidário-ideológica importa, porque sugere qualidades dos partidos de origem das re- presentantes e, ademais, aponta para preferências por questões relevantes, tal como a abrangência do poder do Estado na economia e na promoção do bem-estar social. Assim sendo, conhecer sua ideologia manifesta pode permitir antecipações sobre seu comportamento no âmbito do parlamento. Afınal, quem são elas e o que podem querer alcançar no desempenho da função de representar?

Tabela 3: Distribuição ideológica por sexo (\%)

\begin{tabular}{|c|c|c|c|c|c|c|c|c|c|c|}
\hline \multicolumn{2}{|c|}{} & Leg. 47 & Leg. 48 & Leg. 49 & Leg. 50 & Leg. 51 & Leg. 52 & Leg. 53 & Leg. 54 & Total \\
\hline \multirow{4}{*}{ Mulheres } & Direita & 50 & 46,2 & 31,0 & 21,7 & 23,3 & 21,8 & 25,4 & 26,2 & 27,0 \\
\cline { 2 - 11 } & Centro & 30 & 30,8 & 24,1 & 43,5 & 37,2 & 27,3 & 23,7 & 18,5 & 28,5 \\
\cline { 2 - 12 } & Esquerda & 20 & 23,1 & 44,8 & 34,8 & 39,5 & 50,9 & 50,8 & 55,4 & 44,4 \\
\cline { 2 - 12 }$y$ & $\mathrm{~N}$ & 10 & 26 & 29 & 46 & 43 & 55 & 59 & 65 & 333 \\
\hline \multirow{4}{*}{ Homens } & Direita & 52,9 & 36,4 & 50,7 & 45,1 & 41,5 & 37,5 & 37,4 & 37,4 & 42,3 \\
\cline { 2 - 12 } & Centro & 41,1 & 54,3 & 33,2 & 36,9 & 37,7 & 33,0 & 31,5 & 29,4 & 37,0 \\
\cline { 2 - 12 } & Esquerda & 6,0 & 9,3 & 16,1 & 18,1 & 20,8 & 29,5 & 31,2 & 33,2 & 20,7 \\
\cline { 2 - 11 } & $\mathrm{N}$ & 654 & 657 & 690 & 708 & 721 & 682 & 693 & 698 & 5503 \\
\hline
\end{tabular}

Fonte: elaboração própria, com base em dados dos sites do Senado federal e da Câmara dos Deputados.

A tabela $3^{14}$ confirma o que diz a literatura sobre a maior propensão dos partidos de esquerda para recrutar mulheres. Legisladoras de esquerda ocuparam 44,4\% dos mandatos no Congresso entre 1987 e 2015. Percentual bem superior aos dos homens: 20,7\%. Um dado interessante da literatura acerca dos políticos de esquerda é sua maior tendência - em relação a políticos do centro e da direita - a se engajarem e ob- terem treinamento político em movimentos e organizações sociais antes da entrada nos partidos e na disputa por cargos eletivos (MARENCO; SERNA, 2007). Esse é mais um dado que subsidia considerações sobre o perfil a se formar no correr do processo de profissionalização político das mulheres.

Passa-se, então, à análise das experiências femininas (em comparação às masculinas) externas à casa em que as mulheres

14. As posições ideológicas dos partidos foram definidas tendo por base a literatura (Santos e Almeida, 2005; Campos e Machado, 2014). Para o caso de partidos não mobilizados nos estudos consultados o posicionamento ideológico se baseou em pesquisa própria sobre a história e o perfil dos partidos políticos. Foram posicionados na esquerda PCdoB, PCB, PDT, PPS, PSTU, PT, PTdoB, PMN, PV e PSOL; no centro estão PMDB, PSDB; na direita estão DEM/PFL, PAN, PDC, PDS, PJ, PL, PMB, PP, PPB, PPL, PPR, PR, PRB, PRN, PRONA, PROS, PRP, PRS, PRTB, PSC, PSD, PSDC, PSL, PST, PTB, PTR. 
atuavam na legislatura. Foram consideradas: (a) experiências prévias nos legislativos municipais, estaduais e federal - Senado e Câmara; (b) ocupação de chefia dos executivos nos três níveis de governo (vices inclusive); (c) exercício de chefia em secretarias municipais, estaduais e ministérios. Nos gráficos 8 a 16, mostram-se dados sobre a experiência dos e das parlamentares por nível de governo, instância e sexo.

Gráfico 8 - Legislativo municipal (\%)

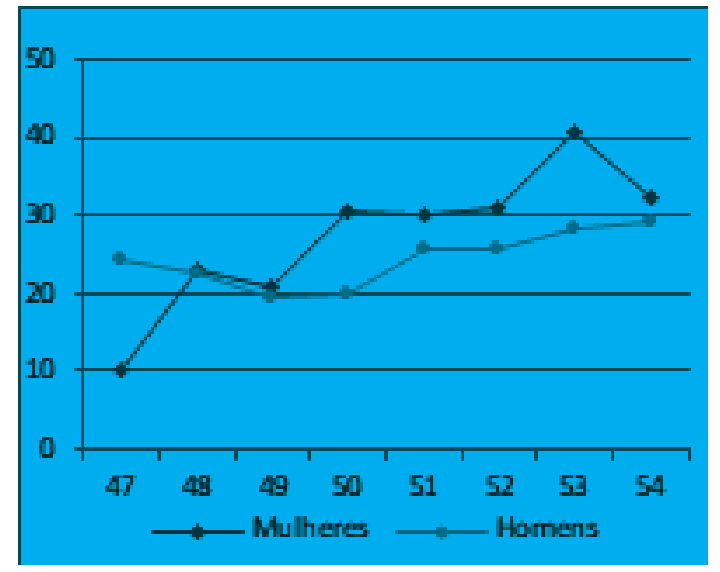

Gráfico 9 - Legislativo estadual (\%)

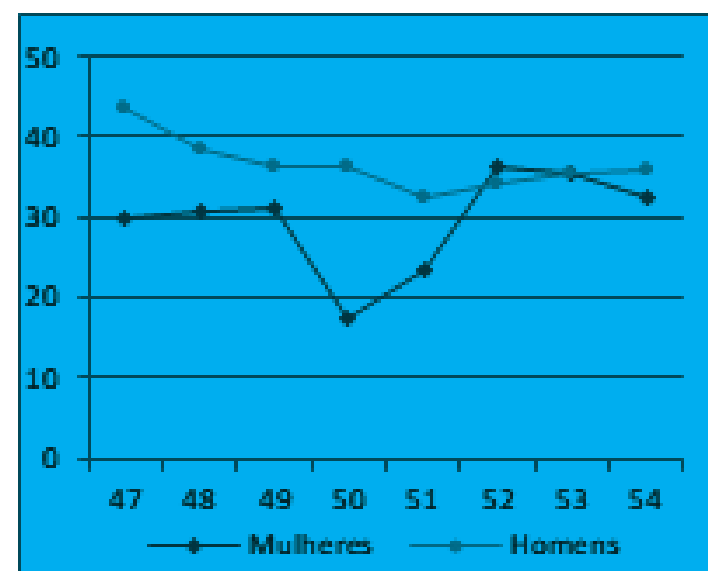


Gráfico 10 - Legislativo federal (\%)

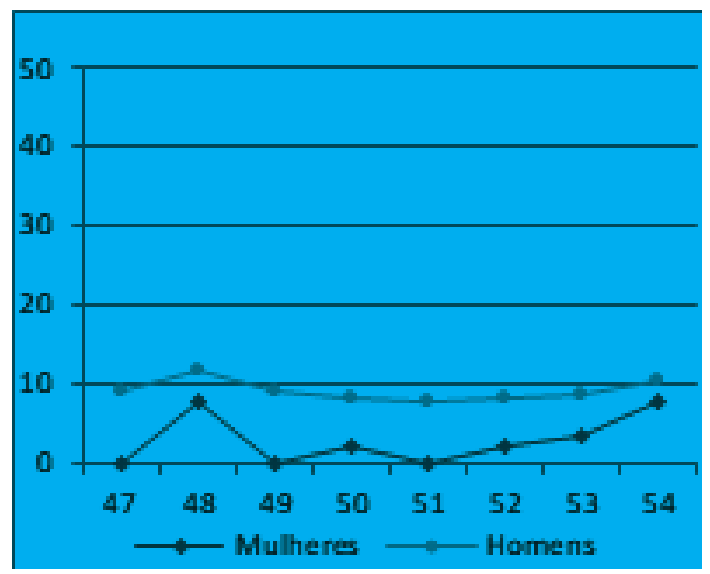

Gráfico 11 - Executivo municipal (\%)

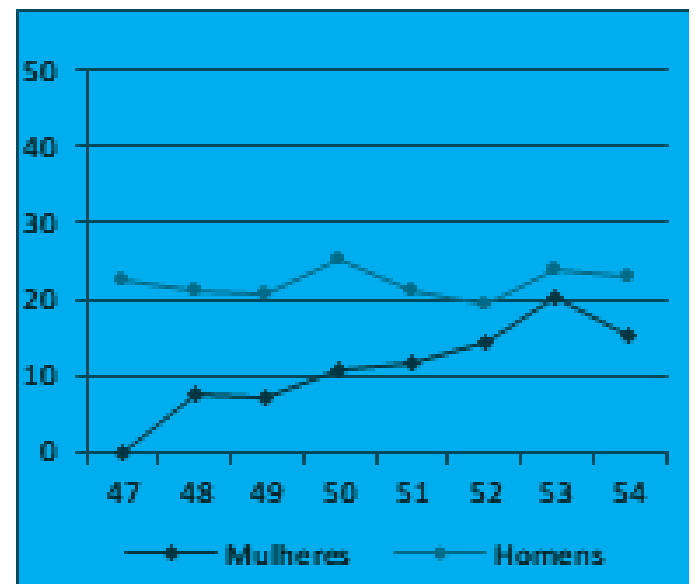

Gráfico 12 - Executivo estadual (\%)

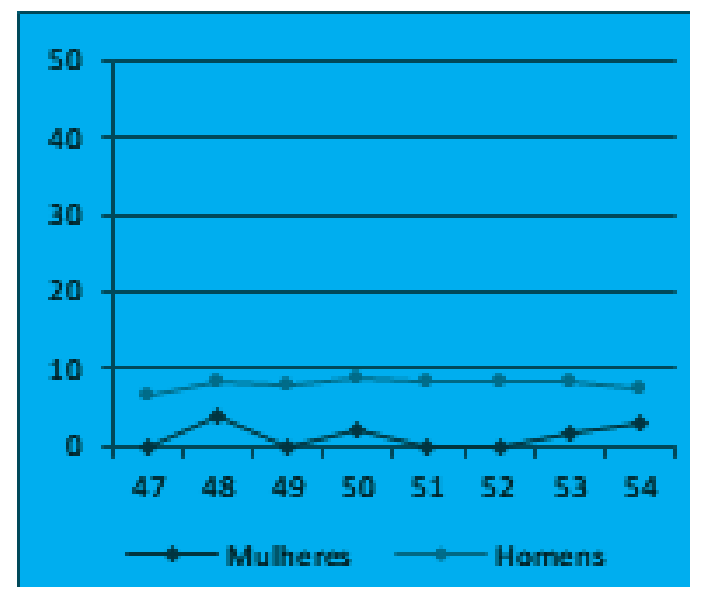


Gráfico 13 - Executivo federal (\%)

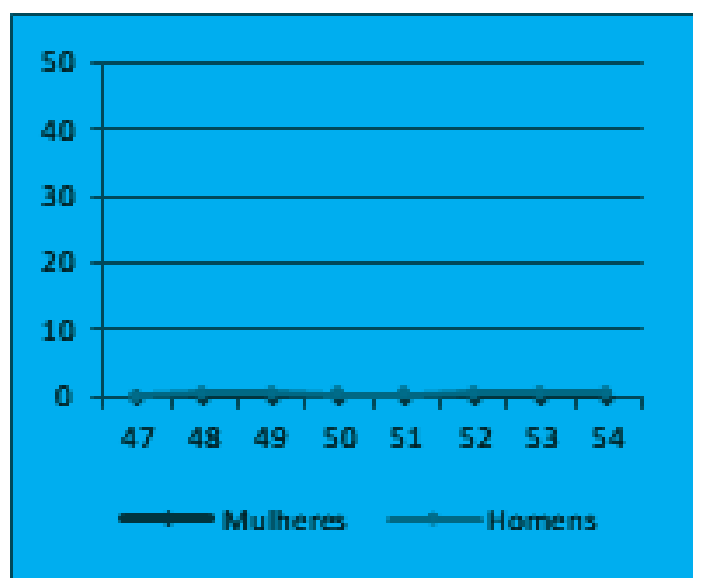

Gráfico 14 - Admin. Municipal (\%)

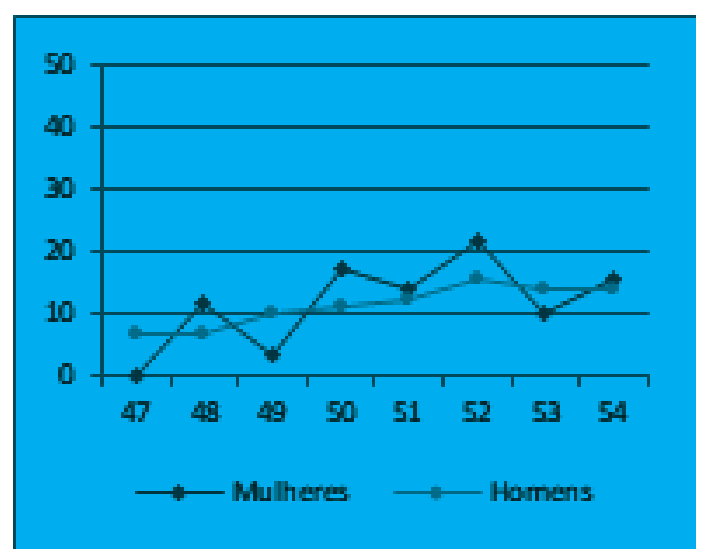

Gráfico 15 - Admin. Estadual (\%)

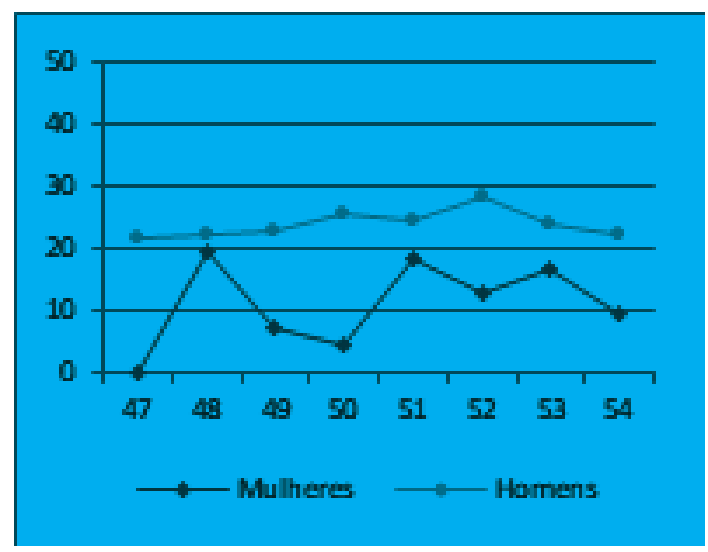




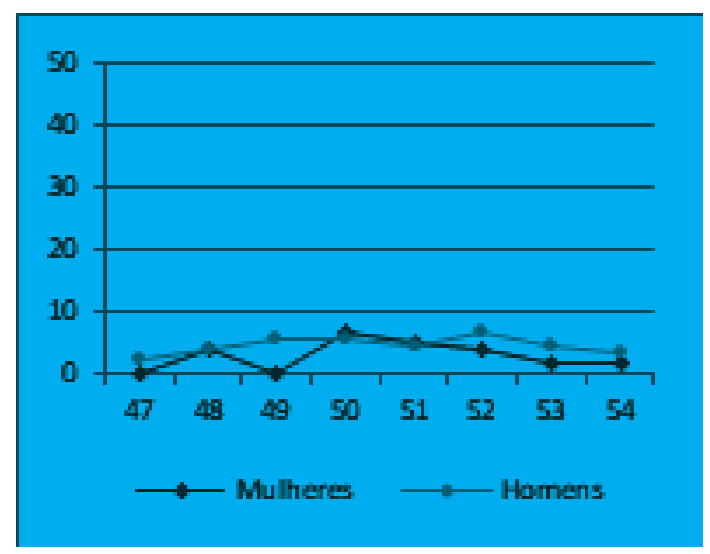

Fonte: elaboração própria, com base em dados dos sites do Senado federal e da Câmara dos Deputados.

0 percentual de experiência prévia das mulheres no Legislativo municipal superou o dos homens a partir da 49a Legislatura. 0 nível médio de experiência das mulheres no poder legislativo cresceu em todos os níveis, apesar de acentuadas oscilações nos níveis estadual e federal. Importa esclarecer que os dados sobre experiências no nível federal consideram apenas a experiência anterior e externa à casa legislativa ocupada na legislatura em questão. Em relação às experiências prévias no próprio Congresso, foi considerada a passagem pela Câmara, por parte das senadoras, e pelo Senado, por parte das deputadas.

Nos executivos, as mulheres demonstram experiência média abaixo da dos homens, embora a tendência no período tenha sido de aumento da experiência feminina agregada em prefeituras e governos estaduais. A Presidência da República foi o único lugar jamais ocupado por uma mulher congressista. Entre os homens, a linha no gráfico próxima do zero mostra que houve muitos poucos casos. Apenas Fernando Collor, José Sarney, Itamar Franco e Marco Maciel retornaram ao Senado depois de terem ocupado a Presidência da República.
A atuação das mulheres em cargos da administração pública é a parte mais oscilante de suas trajetórias, bem diferente dos homens, que mostram percursos mais estáveis ao longo das legislaturas. No nível municipal houve melhor desempenho feminino, embora oscilante, com desempenho superior ao masculino nas legislaturas 48, 50, 51, 52 e 54. Vale notar, ainda, a tendência de alta na taxa da ocupação de cargos nos três níveis de governo, sugerindo que as mulheres têm tentado - e conseguido - ampliar o leque de experiências político-institucionais.

A consideração da trajetória política das congressistas revela, portanto, acúmulo de experiências, aprimoramentos funcionais e conhecimentos em virtualmente todos os cargos eletivos e não eletivos da estrutura federativa. Conforme os dados sugerem, a despeito de ser minoria numérica frente aos homens, boa parte delas acumulou subsídios para atuação na política como profissionais, em níveis equiparáveis aos masculinos. As mulheres, assim como os homens, têm sabido explorar a estrutura de oportunidades característica do sistema federativo brasileiro, que incentiva e permite o acú- 
mulo de experiências nos diversos níveis e nas diversas instâncias do sistema político.

Por fim, serão apresentadas duas outras variáveis que ajudam a avaliar as relações de deputadas e senadoras com a função representativa no nível federal. Ajudam, ademais, a perceber os fatores envolvidos em sua trajetória de acesso ao Congresso Nacional. São elas: a taxa de renovação do contingente feminino e o tempo médio de experiência prévia na mesma casa - o que a literatura denomina senioridade, do inglês seniority.

Poslby (1968), num conhecido estudo sobre o Casa dos Representantes dos Estados Unidos, mostrou uma tendência his- tórica do legislativo federal americano de fechamento ao ingresso de novatos. Para o autor, isso seria expressão da institucionalização do parlamento como corpo autônomo em seu funcionamento e suas regras de recrutamento. Nesses ambientes, os parlamentares se especializam na política, aprimoram seu contato com os eleitores e apoiadores e se reelegem reiteradamente. Enfim, assim como a casa na qual atuam, os parlamentares também se "institucionalizam" como tais. Desenvolvem e consolidam habilidades que são cada vez mais indispensáveis à sobrevivência política. Eles se tornam profissionais.

Gráfico 17 - Parlamentares estreantes, por sexo (\%)

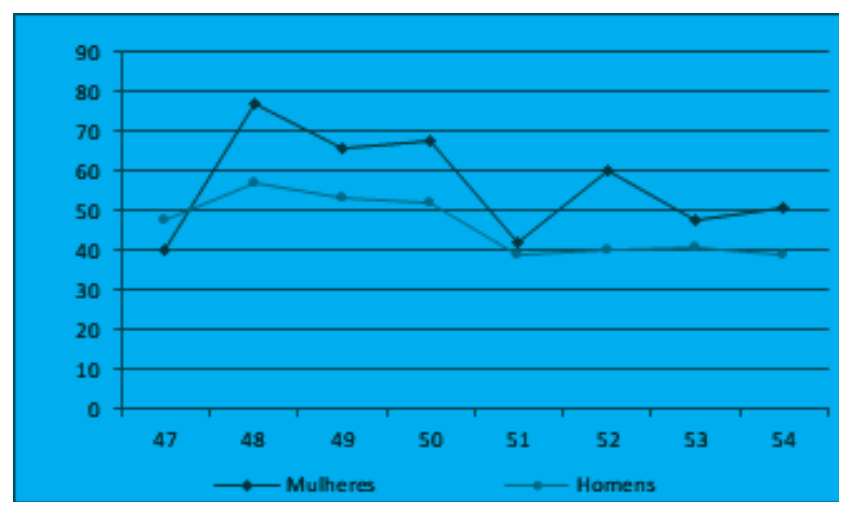

Fonte: elaboração própria, com base em dados dos sites do Senado federal e da Câmara dos Deputados.

A concordar com Polsby, é razoável supor que o gráfico 17 aponta, ainda que discretamente, para o aumento das restrições à entrada de novatos no Congresso Nacional. Embora as conclusões de pesquisadores brasileiros sejam alvo de polêmica (vide SANTOS, 2010; DI MARTINO, 2009, PEGURIER, 2009 VERSUS MAINWARING, 1997; AMES, 2000), elas apontam que as taxas de renovação da Câmara dos Deputados têm caído, e têm aumentado as tentativas de reeleição bem-sucedidas. Esse fenômeno indica uma maior profissionalização parlamentar no nível federal. No caso das mulheres, tendo em vista que seu contingente está aumentando no Congresso, ainda que lentamente, a diminuição da entrada de novatas pode indicar o aumento da capacidade feminina para a manutenção dos mandatos. Isso significa, de algum modo, o aumento da restrição à entrada de outsiders do sexo feminino. 
Gráfico 18 - Senioridade média, por sexo. (número médio de anos em mandatos anteriores, na mesma casa)

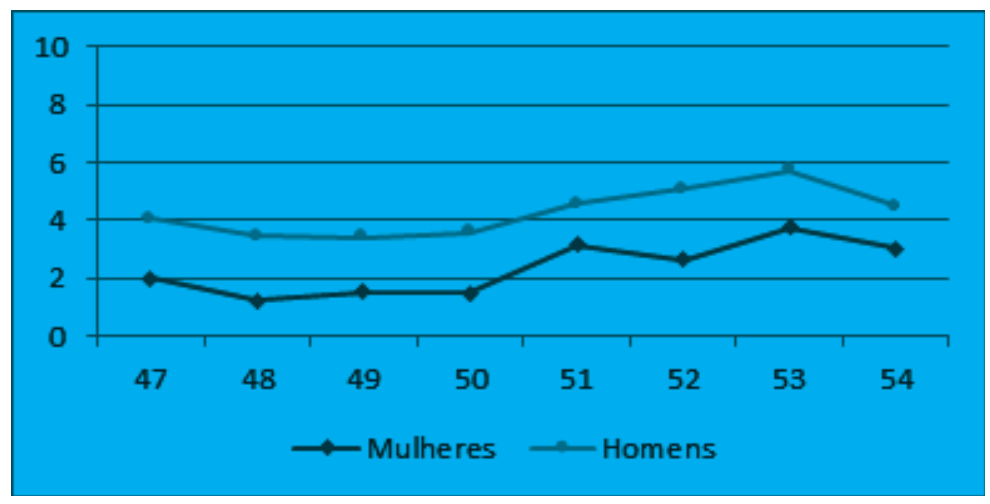

Fonte: elaboração própria, com base em dados dos sites do Senado federal e da Câmara dos Deputados.

0 gráfico 18 reforça esse argumento, pois mostra que a senioridade média das mulheres, como a dos homens, tendeu ao aumento no período, embora tenha caído na última legislatura estudada.

A despeito de o tempo médio de permanência na casa ser baixo - mandatos de deputados são de quatro anos e de senadores são de oito -, os dados são indicadores positivos de estabilização das e dos parlamentares nos cargos e de compromisso com a função. Vale informar que a legislatura em vigor, iniciada em 2015, não foi computada, o que aumentaria um pouco mais a média de anos no cargo, seja pelos homens, seja pelas mulheres - a deputada Perpétua Almeida, do PCdoB, que frequentou os quatro últimos mandados do período estudado, está agora no seu quinto mandato consecutivo.

No todo, o artigo mostra que permanecem certas desvantagens das mulheres em relação aos homens, decorrentes de obstáculos sociais e institucionais. A tradicional hegemonia masculina na representação congressual se expressa, na atualidade, tanto em termos numéricos quanto no tocante ao controle dos homens sobre os cargos de poder. No entanto, as mulheres têm avançado na luta por equidade na representação. A desvantagem numérica, de onde muitas outras surgem, talvez seja a questão mais grave e difícil de ser superada. A questão sai do parlamento e recai na sociedade, pautada por valores e tradições adversos às minorias, e nos partidos políticos, com estruturas e lideranças ainda muito fechadas às demandas por equidade entre mulheres e homens.

\section{Considerações finais}

0 artigo pretendeu contribuir com a discussão sobre a inclusão política das minorias, tendo por foco o problema específico da exclusão política das mulheres. Estas, embora sejam maioria na sociedade brasileira, são minoritárias nos espaços de poder político, particularmente no legislativo federal.

Argumentou-se, em convergência com uma vasta literatura sobre o tema, que a inclusão política das mulheres, como de qualquer minoria, carece de instituições que alterem efetivamente a prática das organizações politicas releventes - com des- 
taque para os parlamentos e os partidos políticos - de modo a incluir de fato, e não apenas formalmente, os segmentos sociais alijados da vida política.

Nesta linha de argumentação, justificou-se a criação de cotas e outros dispositivos formais de participação, intra e extrapartidários, para favorecer as mulheres, não “apenas no papel”, mas também como dispositivos funcionalmente efetivos, assentados em suporte organizacional efetivo e eficaz para tornar de fato as mulheres - e demais minorias - competitivas e com posições consolidadas na estrutura do poder.

A essas questões de cunho normativo conectou-se a discussão de caráter empírico sobre a profissionalização política. Parte da literatura promove um viés da discussão sobre profissionalização, entendendo-a como expressão do elitismo, cuja consequência mais evidente seria a separação radical entre os representantes e a sociedade. Este artigo seguiu orientação distinta, tratando da profissionalização como expressão de uma necessidade de qualificação para a atuação eficiente nas estruturas complexas de poder, tais como o sistema eleitoral, as organizações partidárias e os parlamentos.

Defendeu-se que, para uma atuação relevante na política, as mulheres, tanto quanto os homens, têm de se profissionalizar, de modo tal que as habilidades e qualifıcações obtidas com a profıssionalização propiciem uma relação constante, dinâmica, responsiva e responsável, que não implique elitismo e comprometimento da representação democrática - nos termos defendidos por autoras como Pitkin (1983), Urbinati (2006), Young (2001, 2006).

A parte empírica do artigo avaliou dados sobre o perfil social e as trajetórias políticas de homens e mulheres, buscando identificar sinais de profissionalização do contingente feminino do Congresso Nacional. Foram avaliados dados sobre o background social e as trajetórias políticas das mulheres, em comparação com os homens, e se notou que as mulheres, embora muito pouco representadas em termos percentuais, têm mostrado um desempenho equiparável ao dos homens que chegam ao Congresso Nacional. 0 artigo mostrou que a estrutura federativa também afeta as trajetórias políticas femininas, fazendo com que elas acumulem um vasto leque de experiências nas diversas instâncias e nos diversos níveis de poder na estrutura federativa nacional. Os dados mostraram, ainda, o crescimento da estabilidade das mulheres no poder, com tendência a assegurar experiências cada vez mais duradouras no Congresso Nacional.

Os dados empíricos, por seus limites, não fundamentam conclusões normativas acerca da qualidade democrática da representação feminina. A rigor, os vícios do sistema que afetam a representação em geral induzindo ao criticado elitismo também podem afetar as conexões entre mulheres representantes e suas bases sociais; isso precisa ser estudado. Os dados mostram, no entanto, que as mulheres, embora ainda em percentual relativamente baixo, vêm gradativamente construindo carreiras consolidadas na estrutura política nacional e, particularmente, no parlamento federal. Os dados mostram ainda que, do ponto de vista das virtudes esperadas de um político profissional, as mulheres não deixam margens para dúvidas de que o lugar da mulher é onde ela quiser - inclusive na política. 


\section{Referências bibliográficas}

AMES, B. The Deadlock of Democracy in Brazil. Ann Arbor: Michigan University Press, 2000.

ARAUJO, C. Partidos políticos e gênero: mediações nas rotas de ingresso das mulheres na representação política. Revista de Sociologia Política, n. 24, p. 193-215, 2005.

ARAUJO, C. Gênero e acesso ao poder legislativo no Brasil: as cotas entre as instituições e a cultura. Revista Brasileira de Ciência Política, Brasília, n. 2, p. 23-59, jul./dez. 2009.

ARAÚJO, P. M. Perfil parlamentar e composição das comissões no Senado Federal. In: Anais do VIII Encontro da Associação Brasileira de Ciência Política. Gramado, 2012.

BARBOSA, F. M. F. A influência do gênero na escolha profissional. Recife. 68 p. Monografia de graduação. Ciências Sociais. UFRPE, 2007.

BENHABIB, S. (Org.). Democracy and difference: contesting the boundaries of the political. Princeton: Princeton University Press, 1996.

BEST, H., COTTA, M. (Orgs.). Parliamentary Representatives in Europe: 1848-2000. 0xford: Oxford University Press, 2000.

BITTAR, E. C. Reconhecimento e direito à diferença: teoria crítica, diversidade e a cultura dos Direitos Humanos. Revista da Faculdade de Direito da Universidade de São Paulo, São Paulo. v. 104, p. 551-565, jan. -dez., 2009

CAMPOS, L. A.; MACHADO, C. A. A raça dos (in) eleitos. Insight Inteligência, out.-dez., 2014.

CODATO, A.; COSTA, L. D.; MASSIMO, L. (Orgs.). Retratos da classe política brasileira: estudos de ciência política. Saarbrüken: Editora Novas Edições Acadêmicas, 2015

COSTA, L. D.; BOLOGNESI, B.; CODATO, A. 0 recrutamento político e a questão de gênero no Parlamento brasileiro. In: Codato, A.; Costa, L. D.; Massimo, L. (eds.). Retratos da classe política brasileira: estudos de ciência política. Saarbrü- ken: Editora Novas Edições Acadêmicas, 2015.

COSTA, L. D.; CODATO, A. Profissionalização ou popularização da classe política brasileira? In: Codato, A.; Costa, L. D.; Massimo, L. (Orgs.). Retratos da classe política brasileira: estudos de ciência política. Saarbrüken: Editora Novas Edições Acadêmicas, 2015.

DI MARTINO, M. A política como profissão uma análise da circulação parlamentar na Câmara dos Deputados (1946-2007). São Paulo. Tese de doutorado. Ciência Política. USP, 2009. PHILLIPS, A. De uma política de idéias a uma política de presença? Revista de Estudos Feministas, Florianópolis , v. 9, n. 1, p. 268-290, 2001.

HONNETH, A. 2003. Luta por reconhecimento: a gramática moral dos conflitos sociais. São Paulo: ed. 34, 1992.

KATZ, R.; MAIR, P. (Orgs.), Party Organizations: a data handbook on party organizations in Western Democracies. Londres: Sage, 1992.

MAINWARING, S. Multipartism, Strong Federalism, and Presidentialism in Brazil. In: MAINWARING, S.; SHUGART, M. S., (Orgs.), Presidentialism and Democracy in Latin America, New York and Cambridge: Cambridge University Press, p. 55-109, 1997.

MANIN, B. As Metamorfoses do Governo Representativo. Revista Brasileira de Ciências Sociais, n² 29, p. 5-34. 1995.

MANIN, B.; PRZEWORSKI, A.; STOKES, S. C. Eleições e representação. Lua Nova, São Paulo, n. 67, p. 105-138, 2006.

MARENCO, A.; SERNA, M. Por que carreiras políticas na esquerda e na direita não são iguais? Recrutamento legislativo em Brasil, Chile e Uruguai. Revista Brasileira de Ciências Sociais, São Paulo, v. 22, n. 64, p. 93-113, Jun. 2007

MARENCO, A. Nas fronteiras do campo político: raposas e outsiders no Congresso Nacional. Revista Brasileira de Ciências Sociais, São Paulo, v. 33, p. 98-99, 1998. 
MATOS, M.; CIPRIANO, B.; BRITO, M. Cotas de Gênero para o reconhecimento das Mulheres na Política: Um estudo comparado ações afırmativas no Brasil, Argentina e Peru. In: Anais do XIII Congresso Brasileiro de Sociologia. Recife, 2007.

MENEGUELO, R. El impacto de la democratización del Estado en el desarrollo de los partidos brasileños”. In: CAVAROZZI, M.; MEDINA, J. A. (Orgs.). El asedio a la Política: los partidos latinoamericanos en la Era Neoliberal. Rosário: Konrad-Adenauer e HomoSapiens Ediciones, 2003.

MIGUEL, L. F., 2008. Political Representation and Gender in Brazil: Quotas for Women and their Impact. Bulletin of Latin American Research. Brasília. n. 27 vol. 2, pp.197-214, mar. 2008.

MOUFFE, C. Democracia, cidadania e a questão do pluralismo. Política e Sociedade. Florianópolis. n. 03, p. 11-26, out. 2003.

MUSSINHATO, R. "Quem são os deputados brasileiros? Um balanço do perfil biográfico de 1986 a 2012”. In: Moisés, J. A. 0 Congresso Nacional, os partidos políticos e o sistema de integridade: representação, participação e controle interinstitucional no Brasil. Rio de Janeiro: Konrad Adenauer Stiftung, 2014.

NORRIS, P. Recrutamento político. Rev. Sociol. Polit. Santa Catarina. vol.21, n.46, p.11-32, Jun. 2013.

NOVARO, M. 0 debate contemporâneo sobre a representação política. Revista Novos Estudos. São Paulo. n. 42, vol. 2, Jul., 1995.

OKIN, Susan Moller. Gênero, o público e o privado. Revista Estudos Feministas, v. 16, n. 2, 2008.

PATEMAN, C. Participação e Teoria Democrática. Rio de Janeiro: Paz e Terra, 1992.

PATEMAN, Carole. Críticas feministas a la dicotomía público/privado. In: Perspectivas feministas en teoría política. Barcelona: Paidós. 1996.

PEGURIER, F. Carreiras Políticas e a Câmara dos Deputados Brasileira. Rio de Janeiro. 128 p. Tese de Doutorado. Ciência Política. IUPERJ, 2009.
PERISSINOTO, R.; CODATO, A. (Orgs.). Como estudar elites. Curitiba: UFPR, 2015.

PERISSINOTO, R.; BOLOGNESI, B. Sucesso eleitoral nas disputas para a Câmara dos Deputados. CODATO, A.; COSTA, L. D.; MASSIMO, L. (eds.). Retratos da classe política brasileira: estudos de ciência política. Saarbrüken: Novas Edições Acadêmicas, 2015.

PITKIN, H. 0 conceito de Representação. In: CARDOSO, F. H. E MARTINS, C. E. Política \&t Sociedade (vol. 2). Cia. Editora Nacional: São Paulo, 1983.

PITKIN, H. Representação: palavras, instituições e idéias. Lua Nova, São Paulo, n. 67, p. 15-47, 2006.

POLSBY, N. The institutionalization of the U.S. House of Representatives. American Political Science Review, vol. 62, n¹, p. 47-60, 1968.

SANTOS, F. Câmara dos Deputados e a estrutura de oportunidades políticas no Brasil: alguns apontamentos acerca das eleições de 2010. Cadernos ASLEGIS. Brasília. n. 40, vol. 1, p. 129126, maio-ago., 2010.

SANTOS, F., ALMEIDA, A. Teoria Informacional e a Seleção de Relatores na Câmara dos Deputados. DAD0S, Rio de Janeiro, v. 48, n. 4, p. 693-735, 2005.

SEN, A. Desenvolvimento como liberdade. São Paulo: Companhia das Letras, 2010.

SIMONI JR., S; MUSSINHATO, R. MINGARDI, L. 0 perfil biográfico do "alto clero" da Câmara dos Deputados no Brasil (1995-2010). In: Anais do Seminário Internacional de Ciência Política. 2015.

SPOHR, A. P. et al. Participação Política de Mulheres na América Latina: o impacto de cotas e de lista fechada. Revista de Estudos Feministas, Florianópolis, v. 24, n. 2, p. 417-441, ago. 2016.

SQUIRE, P. Career Opportunities and Membership Stability in Legislatures. Legislative Studies Quarterly. Washington. n. 1, v. 13, p. 65-82, 1988. 
URBINATI, N. 0 que torna a representação democrática? Lua Nova, São Paulo, n. 67, p. 191-228, 2006.

WEBER, M. Ensaios de Sociologia. São Paulo: Abril Cultural, 1974.

YOUNG, I. Comunicação e o outro: além da teoria deliberativa. In: SOUZA, J. (org) Democracia hoje. Brasília: Ed. UNB, 2001.

YOUNG, I. Representação política, identidade e minorias. Lua Nova, São Paulo, n. 67, p. 139190, 2006. 
RESUMO

Frente à defesa normativa da participação das mulheres nos espaços de poder, o texto analisa os mandatos de homens e mulheres no Congresso Nacional da $47^{\text {a }}$ à 54ª Legislatura. Ao todo, são 5860 casos, sendo 5527 de homens e 333 de mulheres. Pesquisas apontam crescente profissionalização das elites legislativas federais, expressa no acúmulo de cargos políticos ocupados até a chegada ao Congresso. Nesse processo, intensifica-se a competitividade que, por sua vez, exige maior profissionalização parlamentar. Por essa lógica, o estudo pressupôs que também o contingente feminino é induzido a níveis mais altos de qualificação política. A despeito dos obstáculos enfrentados para ascensão feminina ao poder, e considerando-se que a mobilização feminina pela igualdade política é ainda recente no Brasil, verificou-se que as deputadas e senadoras têm graus elevados de qualificação, embora inferiores aos dos homens. Verificou-se, ainda, que as mulheres, como os homens, chegam ao Congresso com experiências em postos políticos variados, conforme incentivado pela estrutura do federalismo brasileiro.

\section{PALAVRAS-CHAVE}

Mulheres. Homens. Parlamentares federais. Congresso Nacional. Representação política.

\section{ABSTRACT}

Faced with the normative defense of women's participation in places of power, the text analyzes the mandates of men and women in the National Congress of the 47th to the 54th Legislature. Altogether, there are 5860 cases, 5527 of men and 333 of women. Surveys point to the growing professionalism of federal legislative elites, expressed in the accumulation of political positions held until their arrival in the Congress of Chambers. In this process, competitiveness is intensified, which, in turn, demands greater parliamentary professionalization. By this logic, the study presupposed that the female contingent is also induced to higher levels of political qualification. Despite the obstacles faced by women's rise to power, and considering that women's mobilization for political equality is still recent in Brazil, it has been found that women who take the role of Deputies and Senators have high degrees of qualification, even though inferior to men who also are in the same position. It was also verified that women, like men, arrive at the Congress with experiences in diversified political positions, as encouraged by the structure of Brazilian federalism.

\section{KEYWORDS}

Women. Men. Federal Parliamentarians. National Congress. Political representation.

Recebido em: 11/01/2018

Aprovado em: 01/04/2019 